\title{
The Study of Implementation SETS Approach to Improve Students' Critical Thinking Skills
}

\author{
Wardatul Aini ${ }^{1 *}$, Fida Rachmadiarti ${ }^{1,}$ Prabowo Prabowo ${ }^{1,}$ \\ Eko Hariyono $^{1,}$ Binar K. Prahani ${ }^{1}$
}

\author{
${ }^{1}$ Universitas Negeri Surabaya, Indonesia. \\ *Corresponding Author.Email: wardatul.20029@mhs.unesa.ac.id
}

\begin{abstract}
Some skills need to be developed in the 21 st century, namely communication, collaboration, critical thinking and problem solving, and creativity. SETS is an approach in learning activities that consists of four components, namely science, technology, environment, and society. This approach is applied in learning activities in increasing critical thinking of students. The method of this research is qualitative-descriptive by reviewing 20 journals. The results of the study show that there are applications of the SETS approach integrated with other learning models and methods in learning. SETS approach link subject with daily life problems, use science to analyze the problem, use technology to design the problem solving, and consider the impacts on the environment and society. The integrations are proven can increase critical thinking of students. Further research should be more creative to apply SETS approach by designing and integrating it with other learning models, so it will be effective to develop critical thinking of students.
\end{abstract}

Keywords: 21st-century skills, Critical thinking skills, Literature review, Learning activities, SETS.

\section{INTRODUCTION}

The ability to think is one of the assets that must be developed for students to face the science and technology development in the 21 st century [1][2][3][4]. Critical thinking is an ability that can stimulate other abilities such as logical thinking, creativity, evaluating evidence, assumptions, and logic, problem-solving, and decision making [1][4][5][6]. Some competencies such as critical thinking are developed by facilitating students with learning activities that are related to students' daily life [6][7][5]. Learning activities carried out by teachers cause students' critical thinking skills in low value [4][5]. This presents a challenge for researchers to try new innovations in learning to improve students' critical thinking skills.

The low critical thinking ability of students is influenced by several factors such as the conventional and teacher-centered learning model [5][6]. The results of observations show that one of the factors that influence learning is still rote learning, not meaningful learning [7]. In addition, teachers do not involve students in learning activities, and subject matter was less associated with the science and technology development and its impact on the students' environment [8].

The results of Maimunah's research show that in learning activities students must view everything in an integrated manner, namely by connecting the material being studied with the surrounding environment [7]. Students must be actively involved in learning activities and be able to overcome problems that become more meaningful. One of the things that can support this is applying a student-centered learning model or approach [9]. Integration of subject matter with the environment around students such as environmental technology and society can train students' critical thinking skills [10].

Learning that uses the SETS approach attracts students to critically identify and evaluate scientific problems found in the surrounding environment [11]. The SETS approach or in Indonesian is better known as the mutual theme approach, connecting the theory learned with the application of technology, its impact on the environment and also society so that it becomes real and contextual learning [12][13][14]. The learning experience gained through the SETS approach will be obtained directly because it is adapted to the environmental conditions around students. In the 
SETS approach, teachers and students have their roles. Teachers play an important role in creating a mindset for the future and the implications of it and attracting students to think critically in solving existing issues [14]. Based on the description above, the Author will describe the implementation of the SETS approach and its impact on the critical thinking of students.

\section{METHOD}

This study used a literature review method by analyzing 20 journals related to the implementation of the SETS approach and its impact on the critical thinking of students. The author conducted an article search process with search engine Scholar, OSF, and international proceedings. This research concerned to the article from 2016-2021 related to the implementation of the SETS approach and its impact on the Indonesian students' critical thinking skills.

According to Miles and Huberman 1984, the steps in the descriptive qualitative analysis include 1) data collection, which is the process of collecting information in related fields; 2) Data reduction, namely summarizing, choosing the main topics, focusing on the important thing, look for themes and patterns; 3) Data display, most often used for presenting information in qualitative research is narrative text. Furthermore, it is recommended to display information in the form of graphs, networks, or charts; 4) Conclusion, conclusions must be supported by valid evidence, the conclusion should be consistent when the researcher returns to collect information, then the last conclusions are credible conclusions [28].

\section{RESULTS AND DISCUSSION}

The following Table 1 is the results of journal analysis of the implementation SETS approach to improve critical thinking of students. The 20 journals that have been analyzed are indexed by Scholars, OSF, and international proceedings. 
Table 1. Results of journal analysis

\begin{tabular}{|c|c|c|}
\hline No & Journal & Review The Journal \\
\hline 1 & $\begin{array}{l}\text { Jurnal Formatif, Vol } \\
\text { 6, No 2, 2016: 134- } \\
\text { 140. E-ISSN:2088- } \\
\text { 351x. } \\
\text { DOI: 10.30998/for } \\
\text { matif.v6i2.947 [7]. }\end{array}$ & $\begin{array}{l}\text { Author: Maimunah } \\
\text { Journal results: SETS learning in the material of colloidal increase student's } \\
\text { critical thinking skills with } 42 \% \text { of } \mathrm{N} \text {-gain score (medium category), and the } \\
\text { student's scientific attitude was } 72,7 \% \text { (very good category). SETS learning can } \\
\text { increase critical thinking skills of students because the SETS learning stages } \\
\text { are full of thinking, arguing, and discussing. } \\
\text { Study results: Applying SETS approach with its three stages, namely } \\
\text { exploration, introduction, and application stage can increase critical thinking } \\
\text { skills. }\end{array}$ \\
\hline 2 & $\begin{array}{l}\text { Jurnal EduBio } \\
\text { Tropika, Vol 5, No } \\
\text { 1, 2017: 1-53. [5] }\end{array}$ & $\begin{array}{l}\text { Author: Novi marliani, Hasanuddin, Cut Nurmaliah } \\
\text { Journal results: The average of students' critical thinking pretest was } 46,77 \text { that } \\
\text { was in medium category. The implementation of STSE in learning results } \\
\text { increase the average students' critical thinking, it was } 83,00 \text { in very good } \\
\text { category. } \\
\text { Study results: STSE model is recommended to be applied because it has } \\
\text { advantages. One of them is students have the opportunity to get knowledge } \\
\text { and critical thinking skills and act on the results of the analysis by considering } \\
\text { aspects of SETS as a unit does not inseparable. }\end{array}$ \\
\hline 3 & $\begin{array}{l}\text { Jurnal Pendidikan } \\
\text { IPA Indonesia, Vol } \\
\text { 6, No 2, 2017: 318- } \\
\text { 325. DOI: } \\
\text { 10.15294/jpii.v6i2.1 } \\
0680\end{array}$ & $\begin{array}{l}\text { Author: Usmeldi, R. amini, S.Trisna. } \\
\text { Journal results: The development of learning device-based SETS approaches } \\
\text { was in a valid category. The average of critical thinking skills was } 76,9 \text { in good } \\
\text { category. } \\
\text { Study results: The implementation of SETS approach encourages students to } \\
\text { study science as a whole, use science in applications of technology, and study } \\
\text { its impact on the environment and also society. So SETS approach increases } \\
\text { critical thinking. }\end{array}$ \\
\hline
\end{tabular}




\begin{tabular}{|c|c|c|}
\hline No & Journal & Review The Journal \\
\hline 4 & $\begin{array}{l}\text { Journal of } \\
\text { Natural } \\
\text { Science } \\
\text { Education } \\
\text { Research, Vol } \\
1, \text { No } 1,2018 \text { : } \\
57-64[17]\end{array}$ & $\begin{array}{l}\text { Author: Sutria Amanda, Laila khamsatul Muharrami, Irsad Rosidi, Mohammad } \\
\text { Ahied } \\
\text { Journal results: The implementation of the SETS-based problem-based learning } \\
\text { model can improve students' critical thinking skills by } 0.36 \text { in the medium } \\
\text { category. Linking learning directly with everyday problems so that students can } \\
\text { solve problems on a given test. } \\
\text { Study results: improvement of critical thinking skills of students are influenced } \\
\text { by the use of problem-based learning model with SETS train students' problem- } \\
\text { solving skills, so it can also train student's critical thinking skills. }\end{array}$ \\
\hline 5 & $\begin{array}{l}\text { Jurnal Inovasi } \\
\text { Pembelajaran } \\
\text {, Vol 4, No 2, } \\
\text { 2018: } 102- \\
\text { 112. E-ISSN } \\
2460-0873 \\
{[1]}\end{array}$ & $\begin{array}{l}\text { Author: Abdul ghafur and Nahdia Rupawanti Basuki raharjo } \\
\text { Journal results: The improvement of students' critical thinking skills after applying } \\
\text { the SETS approach to learning is } 61.90 \text { in the good category. The SETS approach } \\
\text { helps students to explain the scientific process underlying natural phenomena, } \\
\text { the development of science and technology, and how the development of science } \\
\text { and technology influences the environment and society. This learning approach } \\
\text { prioritizes the learner-based learning, learning by doing, developing social } \\
\text { sensitivity, building and developing a critical and collaborative attitude. } \\
\text { Study results: Students' critical thinking skills can improve after applying the } \\
\text { learning approach because SETS approach builds critical and collaborative } \\
\text { attitude. }\end{array}$ \\
\hline 6 & $\begin{array}{l}\text { Jurnal } \\
\text { Pendidikan } \\
\text { Dasar } \\
\text { Indonesia, } \\
\text { Vol 2, No 2, } \\
\text { 2018: } 59-71 . \\
\text { ISSN: } 2613- \\
9553 \text { [18]. }\end{array}$ & $\begin{array}{l}\text { Author: S. Maulidati, N. Dantes, and N. Tika } \\
\text { Journal results: Students who take learning with the SETS approach get a score } \\
\text { of } 20.47 \text { with a high category. One of the advantages of SETS learning could } \\
\text { improve inquiry skills, solving skills, and process skills in learning. } \\
\text { Study results: The implementation of scientific-based SETS approach can } \\
\text { increase students' curiosity that will give an impact on students' critical thinking } \\
\text { skills in line with students' learning outcomes }\end{array}$ \\
\hline 7 & $\begin{array}{l}\text { Jurnal } \\
\text { Edukasi } \\
\text { Matematika } \\
\text { dan Sains, } \\
\text { Vol } 7, \text { No } 2 \\
\text { 2019: } 82-90 \\
\text { DOI: } \\
\text { 10.25273/jem } \\
\text { s.v7i2.5295 } \\
{[4]}\end{array}$ & $\begin{array}{l}\text { Author: Ismiyatun Khasanah, M. Aji Fathurrohman, Mobinta Kusuma. } \\
\text { Journal results: Experimental class students have a critical thinking skill score in } \\
\text { the high category as many as } 28 \text { people, while in the control class only } 4 \text { people. } \\
\text { Basically, it can be said that through the concept mapping method with SETS } \\
\text { vision, students can see something in an integrated manner by noticing the four } \\
\text { elements of SETS, so as to obtain a deep understanding of the knowledge } \\
\text { possessed by students. } \\
\text { Study results: The implementation concept mapping method with SETS vision } \\
\text { can improve students' critical skills because it can obtain a deep understanding } \\
\text { to students as the impact of critical thinking skills. }\end{array}$ \\
\hline
\end{tabular}




\begin{tabular}{|c|c|c|}
\hline No & Journal & Review The Journal \\
\hline 8 & $\begin{array}{l}\text { Jurnal Tadris } \\
\text { Kimiya, Vol 3, } \\
\text { No 1, 2018: 94- } \\
\text { 103. E-ISSN: } \\
\text { 2527-9637 [19]. }\end{array}$ & $\begin{array}{l}\text { Author: Wulan Sri Wijaya, Tonih Feronika, and Dila Fairusi } \\
\text { Journal results: The average of students' critical thinking skills in the } \\
\text { experimental class is higher than the average of the control class, namely } 81.8 \\
\text { and } 76.8 \text {. After being given different treatment between the experimental and } \\
\text { control classes, overall it appears that the experimental class using the PBL } \\
\text { learning model with the SETS approach, the average score was higher than the } \\
\text { average score of the control class. It is because of differences in instructions } \\
\text { and thinking strategies built by teachers in learning. The learning environment } \\
\text { can affect the scientific thinking styles of students. } \\
\text { Study results: The application of the SETS approach in the PBL model can } \\
\text { affect students' scientific thinking styles, one of which is critical thinking. }\end{array}$ \\
\hline 9 & $\begin{array}{l}\text { International } \\
\text { Journal of } \\
\text { Current } \\
\text { Innovations in } \\
\text { Advanced } \\
\text { Research, Vol } \\
\text { 1, Issue 6, } \\
\text { 2018: } 84-93 \text {. } \\
\text { ISSN: } 2636- \\
6282 \text { [12]. }\end{array}$ & $\begin{array}{l}\text { Author: Susi Harnani, Agus Suyatna, and Noor Fadiawati. } \\
\text { Journal results: The use of SETS vision global warming worksheet obtain the } \\
\text { average posttest results of students' learning outcome of } 86,19 \text { in the high } \\
\text { criteria. With SETS approach, the teacher will be very instrumental in creating } \\
\text { students to have integrative thinking, inviting students to think critically in } \\
\text { dealing with something by referring SETS approach. } \\
\text { Study results: SETS vision global warming worksheet equipped with interactive } \\
\text { multimedia in the form of animation or video that can improve learning } \\
\text { outcome, improve process skills, and learning activities. }\end{array}$ \\
\hline 10 & $\begin{array}{l}\text { Pancasakti } \\
\text { Science } \\
\text { Education } \\
\text { Journal, Vol 4, } \\
\text { No 2, 2019: } \\
\text { 137-142. DOI: } \\
\text { 10.2495/psej.v4 } \\
\text { i2.1437 [9]. }\end{array}$ & $\begin{array}{l}\text { Author: Mega Sylviana, Mobinta Kusuma, and Bayu Widiyanto. } \\
\text { Journal results: The average value of students' critical thinking skills after the } \\
\text { implementation of the probing-prompting-based SETS was } 82.9 \% \text {. The } \\
\text { implementation of SETS can help students understand the lesson because } \\
\text { learning is associated with problems in everyday life. This allows students to } \\
\text { discover new knowledge, solve a problem and participate actively in creating } \\
\text { solutions. } \\
\text { Study results: The implementation of the probing-prompting-based SETS } \\
\text { helps students improve critical thinking skills through the learning experiences } \\
\text { gained. This is in line with the increasing understanding of students }\end{array}$ \\
\hline 11 & $\begin{array}{l}\text { Jurnal } \\
\text { Pendidikan, Vol } \\
\text { 14, No 1, 2020: } \\
\text { 41-51. ISSN } \\
\text { 1858-4497 [6]. }\end{array}$ & $\begin{array}{l}\text { Author: Danty Kusmianty, Bayu Widiyanto, Mobinta Kusuma. } \\
\text { Journal results: The test results of students' critical thinking skills have } \\
\text { increased after using the SETS learning model with the practicum method. The } \\
\text { value obtained in the experimental class is } 80.62 \% \text { in the high category. The } \\
\text { experimental class with the SETS model has a better understanding of the } \\
\text { impact of technology on the environment and society through global warming } \\
\text { materials. }\end{array}$ \\
\hline
\end{tabular}




\begin{tabular}{|c|c|c|}
\hline No & Journal & Review The Journal \\
\hline & & $\begin{array}{l}\text { Study results: The implementation of the SETS learning model with the } \\
\text { practicum method makes students interested in participating in learning } \\
\text { so it increases students' critical thinking skills. }\end{array}$ \\
\hline 12 & $\begin{array}{l}\text { Journal Education } \\
\text { of Young Physics } \\
\text { Teacher, Vol 2, No } \\
\text { 1, 2021: 29-35. E- } \\
\text { ISSN: 2723-8164 } \\
\text { [2]. }\end{array}$ & $\begin{array}{l}\text { Author: Irma, Meriyanti, and Irwandani } \\
\text { Journal results: The implementation of DBUS model with the SETS } \\
\text { approach improves students' critical thinking skills with an N-Gain score } \\
\text { of } 0.53 \text { in the medium category. The SETS approach stimulates student } \\
\text { interest which results in stimulating students to more easily understand } \\
\text { the lesson. } \\
\text { Study results: the implementation of the DBUS model with the SETS } \\
\text { approach can increase students' critical thinking skills along with the } \\
\text { increasing interest and understanding of students in the studied material. }\end{array}$ \\
\hline 13 & $\begin{array}{l}\text { Jurnal Education } \\
\text { and Development, } \\
\text { Vol 8, No 2, } \\
\text { 2020:584-590. E- } \\
\text { ISSN: 2614-6061 } \\
\text { [20]. }\end{array}$ & $\begin{array}{l}\text { Author: Indang Mustiko Rini, Wahono Widodo, and Widowati Budijastuti } \\
\text { Journal results: The development of SETS-based teaching materials is in } \\
\text { a very valid category with a percentage of } 97.66 \% \text {. The use of SETS-based } \\
\text { materials in learning shows student activity with an average of } 81 \% \text {. This } \\
\text { increases students' critical thinking skills by } 60 \% \text { with the medium } \\
\text { category. } \\
\text { Study results: The use of SETS-based teaching materials can improve } \\
\text { students' critical thinking skills as a result of positive responses and } \\
\text { activities during learning activities. }\end{array}$ \\
\hline 14 & $\begin{array}{l}\text { International } \\
\text { Journal of Recent } \\
\text { Educational } \\
\text { Education, Vol 1, } \\
\text { No 3, 2020. E-ISSN: } \\
2721-7965 \text { [10]. }\end{array}$ & $\begin{array}{l}\text { Author: Devy Alvionita, Prabowo, Z.A. Imam Supardi } \\
\text { Journal results: The implementation of the PBL model with the SETS } \\
\text { method resulted from an average of students' critical thinking ability of } 84 \text {. } \\
\text { The increase in students' critical thinking ability was indicated by the N- } \\
\text { Gain score of } 0.7 \text { in the medium category. } \\
\text { Study results: The application of the PBL model with the SETS method } \\
\text { can improve students' ability to solve problems as a result students' ability } \\
\text { to think critically increase. }\end{array}$ \\
\hline 15 & $\begin{array}{l}\text { Jurnal Pembelajar- } \\
\text { an Kimia, vol 5, No } \\
\text { 2, 2020: 78-83. E- } \\
\text { ISSN: } 2579-5945 \\
\text { [11]. }\end{array}$ & $\begin{array}{l}\text { Author: Fariza Anizarini, Endang Budiasih, Dedek Sukarianingsih } \\
\text { Journal results: The influence of POGIL learning with the SETS approach } \\
\text { resulted in an average of } 78.06 \% \text { of students' critical thinking. Students } \\
\text { are trained to use their ability to think critically by linking the science } \\
\text { material being studied with the use of technology and its consequences } \\
\text { for the environment around students. } \\
\text { Study results: The application of the SETS-based POGIL model } \\
\text { familiarizes students with linking subject matter with problems in daily life } \\
\text { can train students' critical thinking skills. }\end{array}$ \\
\hline
\end{tabular}




\begin{tabular}{|c|c|c|}
\hline No & Journal & Review The Journal \\
\hline 16 & $\begin{array}{l}\text { Jurnal Kimia dan } \\
\text { Pendiidkan, Vol 5, } \\
\text { No 2, 2020: } 134-152 \text {. } \\
\text { E-ISSN: } 2502-4787 \\
\text { DOI: } \\
\text { 10.30870/educhemi } \\
\text { a.v5i2.7934 [21]. }\end{array}$ & $\begin{array}{l}\text { Author: Rahmat Rasmawan } \\
\text { Journal results: The development of SETS-based teaching materials are } \\
\text { declared valid and feasible to use. The SETS sequence is presented in a } \\
\text { sequence starting from using science to technology forms to meet the } \\
\text { needs of society, it requires thinking about its implications on the } \\
\text { environment. } \\
\text { Study results: The problems raised in the teaching materials are critical } \\
\text { thinking exercises by presenting issues that are in accordance with their } \\
\text { environment and students can be directly involved in solving these } \\
\text { problems. }\end{array}$ \\
\hline 17 & $\begin{array}{l}\text { Pascasakti Science } \\
\text { Education Journal, } \\
\text { Vol 2, No 2, 2017: } \\
\text { 125-137. E-ISSN: } \\
\text { 2541-0628 [22]. }\end{array}$ & $\begin{array}{l}\text { Author: Pratiwi Oktaviani, Hartono, and Puput Marwoto } \\
\text { Journal results: interactive multimedia development with SETS vision is } \\
\text { valid and feasible to use in learning. The interactive multimedia is effective } \\
\text { in improving students' critical thinking skills. This is indicated by the n- } \\
\text { Gain score of } 0.59 \text { in the medium category. } \\
\text { Study results: The interactive multimedia with SETS vision has problem- } \\
\text { solving stages that can improve students' cognitive abilities. This indirectly } \\
\text { also affects students' critical thinking skills }\end{array}$ \\
\hline 18 & $\begin{array}{l}\text { AIP Conference } \\
\text { Proceedings2330, } \\
020014,2021: 1-5 . \\
\text { 10.1063/5.0043357 } \\
\text { [23]. }\end{array}$ & $\begin{array}{l}\text { Author: Y.D Kusumaningrum, E. Budiarsi, dan Suharti } \\
\text { Journal results: On the integration of the SETS approach with the } 7 E \\
\text { learning cycle model, students obtained an average critical thinking ability } \\
\text { of } 84.07 \text {. The integration of SETS in the } 7 E \text { learning cycle model brings real- } \\
\text { life problems into the classroom to find solutions. } \\
\text { Study results: The integration of SETS with the 7E learning cycle trains } \\
\text { students to use thinking skills to solve problems included critical thinking }\end{array}$ \\
\hline 19 & $\begin{array}{l}\text { Journal of Physics: } \\
\text { conference series, } \\
\text { International } \\
\text { Conference on } \\
\text { Mathematics and } \\
\text { Science Education } \\
2019,2020[24]\end{array}$ & $\begin{array}{l}\text { Author: A S Arota, Mursalin, and A.H Odja. } \\
\text { Journal results: The analysis results of the application of SETS-based e- } \\
\text { learning showed that students' thinking skills increased very high with an } \\
\mathrm{N} \text {-gain score of } 0.72 \text {. } \\
\text { Study results: The application of SETS-based e-learning in learning can } \\
\text { improve critical thinking skills. This is in line with the increase in student } \\
\text { learning outcomes }\end{array}$ \\
\hline 20 & $\begin{array}{l}\text { Jurnal Pendidikan } \\
\text { dan Pembelajaran } \\
\text { Kimia, Vol 10, No 1, } \\
\text { 2021: 49-62.E-ISSN: } \\
\text { 2714-9595 [25]. }\end{array}$ & $\begin{array}{l}\text { Author: Anis Mualifah, dan Rusmini } \\
\text { Journal results: The development of the SETS-based acid-base module is } \\
\text { considered very practical and effective because it improves students' } \\
\text { critical thinking skills with an N-Gain score of } 0.79 \text { in the very high } \\
\text { category. } \\
\text { Study results: implementation of } 3 \text { stages in SETS approach is effective to } \\
\text { increase the critical thinking skills of students. }\end{array}$ \\
\hline
\end{tabular}


The analysis results of 20 journals showed that the implementation of the SETS approach in learning influences student learning activities. This resulted in students' critical thinking skills and responses given by students to learning activities. Students' critical thinking skills are proven to increase and are in the medium to high category. The SETS approach takes into account aspects of science, environment, technology, and society so that it is closely related to students' daily lives [5]. The ultimate goal of the SETS approach is to solve problems that exist in society by involving technological developments. Therefore, the teacher guides students to find issues that exist in the community and solve them based on the SETS [7].

The SETS approach consists of 4 important aspects: 1) Invitation phase, namely the phase of introducing scientific issues or problems that are developing in the community and environment. 2) The exploration phase is the activity of gathering information through observation or experimentation. 3) The explanation phase, which is a combination of the invitation phase and the exploration phase, the students adust the data obtained from observation or experimentation to fit the concept being studied. 4) The application phase, namely the application of skills and knowledge that have been obtained by students into problems related to the concept [26].

Critical thinking indicators can be trained through the SETS approach because the actual problems raised in learning are around students. This helps students get used to thinking critically in solving problems and making decisions [19]. Furthermore, students will create solutions by utilizing the concepts of science and technologies. Students can analyze the impact of the problem-solving plan on the environment and society. Learning that integrates these four important elements is expected to be able to train the critical thinking skills of students [27].

All journals claim that using SETS approach in learning, integrating with other models and methods, can improve critical thinking skills of students. This is because SETS approach uses the problems in daily life. Eventually, the student will feel responsible and be directly involved in solving the problem. That character can help soften during learning with SETS approach. Students are trained to encounter similar problems or global problems in the future.

\section{CONCLUSION}

The implementation of the SETS approach in learning can affect student activities during learning so that students' critical thinking skills increase. Learning tools developed based on the SETS approach have also been proven valid and feasible to use. In addition, the implementation of the SETS approach received a positive response from both students and teachers. The limitation of this research is that the journals analyzed are not journals that only implement the SETS approach, but are still integrated with other models or methods. Future research should be more creative to explore and develop the implementation SETS approach by integrating it with other learning models and methods. Besides, next research must pay attention to developments in science and technology so that the use of SETS is always dynamic and in accordance with the needs in education.

\section{AUTHOR CONTRIBUTION}

Wardatul Aini conducted journal analysis, writed down the results, and discussed them in articles. Fida Rachmadiarti, Prabowo, and Eko Hariyono provided constructive corrections to the journal results and the whole article. Binar K. Prahani provided suggestions for research titles and guided how to construct articles, and also provided constructive corrections on the results of the whole article.

\section{ACKNOWLEDGMENTS}

The author would like to thank the Education Fund Management Institution (LPDP) for encouraging the author to continue the research in education. The author also thanks to the lecturers in Universitas Negeri Surabaya who have guided the author in completing this article.

\section{REFERENCES}

[1] A. Ghofur, N. Rupawanti, and B. Raharjo, Peningkatan Kemampuan Berfikir Kritis Mahasiswa Melalui Pendekatan 5E dan SETS Berbantu Aplikasi Media Sosial, Jurnal Inovasi Pembelajaran, vol. 4, no. November, pp. 102-112, 2018.

[2] Irma, Meriyanti, and Irwani, Model Pembelajaran Discovery Based Unity of Science ( DBUS ) dengan Pendekatan SETS: Pengaruh terhadap Kemampuan Berpikir Kritis pada Masa Pandemi Covid-19, Journal Education of Young Physics Teacher, vol. 2, no.1, pp. 29-35, 2021. DOI: 10.30599/uteach.v2i1.36

[3] A. Nurkhasanah, Use of SETS (Science , Environment, Technology and Society) Approach for Practice the Problem Solving Ability of Elementary School Students in Surabaya, International Journal of innovative Science and Research technology, vol. 4, no. $12,2019$.

[4] I. Khasanah, M. A. Fatkhurrohman, and M. Kusuma, Implementasi Concept Mapping Bervisi SETS Untuk Memberdayakan Kemampuan Berpikir Kritis, Jurnal Edukasi Matematika dan Sains, vol. 7, no. 2, pp. 8290, 2019, doi: 10.25273/jems.v7i2.5295.

[5] N. Marliani, Pengaruh Model Pembelajaran Science, Tehcnologi, Society, Environment (STSE) Terhadap Keterampilan Berpikir Kritis dan Hasil Belajar Siswa Pada Materi Pencemaran Lingkungan di Mas Jeumala 'Amal, Jurnal EduBio Tropika, vol. 5, no. April, pp. 38-43, 2017. 
[6] D. Kusmiyanti, B. Widiyanto, and M. Kusuma, Efektivitas Model Pembelajaran Sets Metode Praktikum Pada Materi Pemanasan Global Dalam Meningkatkan Kemampuan Berpikir Kritis, Jurnal Pendidikan, vol. 14, no. 1, 2020.

[7] Maimunah, Penggunaan Model Pembelajaran Science Environment Technology and Society ( SETS ) untuk Meningkatkan Kemampuan Berpikir Kritis, Jurnal Formatif, vol. 6, no. 2, pp. 134-140, 2016. DOI: $10.30998 /$ formatif.v6i2.947

[8] R. Umami and B. Jatmiko Penerapan Model Pembelajaran Inkuiri Dengan Pendekatan SETS (Science, Environment, Technology and Society) pada Pokok Bahasan Fluida Statis untuk Meningkatkan Keterampilan Berpikir Kritis Siswa Kelas Xi Sma Negeri 1 Gedangan, Jurnal Inovasi Pendidikan Fisika, vol. 02, no. 03, pp. 61-69, 2013.

[9] M. Sylviana, M. Kusuma, B. Widiyanto, and U. P. Tegal, Profil Kemampuan Berpiir Kritis Siswa dengan Implementasi Model Pembelajaran SETS Berbasis Probing-Pompting, Pancasakti Science Education Journal, vol. 4, pp. 137-142, 2019, doi: 10.24905/psej.v4i2.1437.

[10] D. Alvionita and Z. A. I. Supardi, Problem Based Learning with The SETS Method to Improve the Student' s Critical Thinking Skill of Senior High School, International Journalof Recent Educational Education, vol. 1, no. 3, pp. 246-260, 2020.

[11] F. Anizarini, E. Budiasih, and D. Sukarianingsih, Effect of POGIL Learning Model toward Students' Critical Thinking Skills on Buffer Solution Material, Jurnal pembelajaran Kimia, vol. 5, no. 2, pp. 78-83, 2020. DOI: $10.17977 /$ um026v5i22020p078.

[12] S. Harnani, A. Suyatna, and N. Fadiawati, International Journal of Current Innovations in Advanced Research The Effectiveness of Global Warming Worksheet Sets Vision to Improve Students Critical Thinking Skills, International Journal of Current Inovation in Advanced Research, vol. 1, no. 6, pp. 84-93, 2018.

[13] D. Rahmawati, T. rahman, and A. Amprasto, Efforts to Handle Waste through Science, Environment, Technology and Society ( SETS ), International Conference on Mathematics and Science Education (ICMScE), pp. 1-4, 2017. DOI: 10.1088/17426596/895/1/012124.

[14] Usmeldi, R. AArini, and S. Trisna, Jurnal Pendidikan IPA Indonesia The Development of Research-Based Learning Model With Science, Environment, Technology, And Society, Jurnal Pendidikan IPA Indonesia, vol. 6, no. 2, pp. 318325, 2017, doi: 10.15294/jpii.v6i2.10680.

[15] A. Marzali, Menulis kajian Literatur, Jurnal Etnografi Indonesia, vol 01, no, 02, pp. 27-53, 2016. DOI: $10.31947 /$ etnosia.v1i2.1613

[16] I. S. Dewi, Profil Implementasi Model Pembelajaran webbed dalam Mata Pelajaran IPA Terpadu di Indonesia (2013-2021), Jurnal Inovasi Penelitian dan
Pengabdian Masyarakat, vol. 1, no. 1, pp. 16-31, 2021.

[17] S. Amanda, L. K. Muharrami, I. Rosidi, and M. Ahied, Pembelajaran IPA Menggunakan Model Pembelajaran Berbasis Masalah Berbasis SETS, Journal of Natural Science Education Research, Vol 1, No 1, pp. 57-64, 2018.

[18] S. Maulidati, N. Dantes, and N. Tika, Pengaruh Pembelajaran Berpendekatan Saintifik Berorientasi Science Environment Technology Society terhadap Kemampuan Berpikir Kritis dan Hasil Belajar IPA Siswa Kelas V, Jurnal Pendidikan Dasar Indonesia, vol. 2, no. 2, pp. 59-71, 2018.

[19] W. S. Wijaya, T. Feronika, and D. Fairusi, Penerapan Problem Based Learning Berpendekatan SETS Terhadap Keterampilan Berpikir Kritis Siswa, Jurnal Tadrais Kimia 3, vol. 1, no. Juni, pp. 94-103, 2018. DOI: 10.15575/jtk.v3i1.2338.

[20] I. M. Rini, W. Widodo, and W. Budijastuti, Pengembangan Bahan Ajar Ipa Berbasis Science Environment Technology and Society ( SETS ) untuk Melatihkan Keterampilan Berpikir Kritis Siswa Kelas, Jurnal Education and Development, vol. 8, no. 2, pp. 584-590, 2020.

[21] R. Rasmawan, Development of Sets-Based Teaching Materials in Acid-Base Accompanied By Critical Thinking Exercises And Moral, Jurnal Kimia dan Pendidikan, vol. 5, no. 2, pp. 134-152, 2020, doi: 10.30870/educhemia.v5i2.7934.

[22] P. Oktaviani, Hartono, \& P. Marwoto, Pengembangan Multimedia Interaktif SETS sebagai Alat Bantu Model Problem-BAsed Learning (PBL) dalam Pembelajaran IPa di SMP untuk Meningkatkan Kemampuan Berpikir Kritis dan Keterampilan Sosial Peserta Didik Pancasakti Science Education Journal, vol. 2, pp. 125-137, 2017.

[23] Y. D. Kusumanigrum, E. Budiarsih, and Suharti, Effect of integration of SETS ( science- learning cycle on students' critical thinking skills, vol. 020014, 2021. DOI:10.1063/5.0043357.

[24] A.S. Arota, Mursalin, and A. H. Odja, The effectiveness of e-learning based on SETS to improve students' critical thinking skill $\mathrm{s}$ in optical instrument material, Journal of Physics, 2020, doi: 10.1088/1742-6596/1521/2/022061.

[25] A. Mualifah and Rusmini, Acid Base Module with SETS Appproach t Train Students' Critical thinking Skill, Jurnal Pendidikan dan Pembelajaran Kimia, vol. 10, no. April, pp. 49-62, 2021, doi: 10.23960/jppk.v.10.i1.April.

[26] D. Marwah, D. Wahyudin, R. Cynthia, P. Studi, T. Pendidikan, and U. P. Indonesia, Efektivitas Penerapan Model Pembelajaran Science Technology and Society (STS) Terhadap Peningkatan Berpikir Kritis, iedutechnologia,vol. 3, no. 2, pp. 171-182, 2017. 
[27] L. F. Nikmah, Pendekatan Science Environment Technology aand Society (SETS) pendukung kemampuan berpikir tingkat tinggi siswa, pp. 398405, 2018.

[28] Sugiyono, Metode Penelitian Kuantitatif, Kualitatif, dan R\&D, Alfabeta, pp. 247. 2016. 